\title{
Protein and energy metabolism of lactating Granadina goats
}

\author{
BY J. F. AGUILERA, C. PRIETO AND J. FONOLLÁ \\ Estación Experimental del Zaidín (EEZ), 18008 Granada, Spain
}

(Received 12 August 1988 -Accepted 25 October 1989)

\begin{abstract}
Twelve goats of the Granadina breed in mid- and late lactation were used in two consecutive years to determine their protein and energy requirements for lactation. The animals were individually fed on diets based on pelleted lucerne (Medicago sativa) hay and barley. A total of six balance experiments were carried out. Gas exchange was measured using open-circuit respiration chambers. Milk yield ranged widely from 0.649 to $1.742 \mathrm{~kg} / \mathrm{d}$ in the first year and from 0.222 to $1.989 \mathrm{~kg} / \mathrm{d}$ in the second year, a steady decline in milk output being observed as lactation progressed. Milk composition remained rather constant during the midstage of lactation, with an average content (/ $\mathrm{kg}$ milk) for total solids, total nitrogen, fat and gross energy of $149 \cdot 7 \mathrm{~g}, 5.39 \mathrm{~g}, 58.8 \mathrm{~g}$ and $3.59 \mathrm{MJ}$ respectively. Total endogenous $\mathrm{N}$, endogenous urinary $N$ and maintenance requirement for $N$ in lactating goats were estimated to be 244 , $218 \mathrm{mg} \mathrm{N} / \mathrm{kg}$ body-weight $(\mathrm{W})^{0.75}$ per $\mathrm{d}$ and $478 \mathrm{mg}$ total $\mathrm{N} / \mathrm{kg} \mathrm{W}^{0.75}$ per $\mathrm{d}$ respectively from regression equations. A constant efficiency of use of dietary $N$ for milk $N$ plus retained $N$ of $51.0 \%$ was found. By regressing milk energy plus apparent body energy retention or loss on metabolizable energy (ME) intake, the maintenance energy requirement was estimated to be $401 \mathrm{~kJ} \mathrm{ME} / \mathrm{kg} \mathrm{W}^{075}$ per d. When estimating the corrected milk yield as milk energy $+(0.84 \times$ negative energy retention $)+(1.05 \times$ positive energy retention), regression analysis indicated that the overall efficiency of use of $\mathrm{ME}$ for lactation was $66.7 \%$. Also, from a plot of apparent body energy retention $y$. milk energy yield, both expressed as a percentage of ME intake above maintenance, the efficiency with which ME was used to promote energy retention in the body during lactation was calculated to be 0.907 times that for milk secretion.
\end{abstract}

Energy metabolism: Protein metabolism: Goats

Although nutrient requirements are now relatively well-defined in sheep and cattle, there is still a lack of reliable information in the literature about the nutritional needs of lactating goats. Most available information has relied on extrapolations of values derived from cattle and sheep experiments. Nevertheless, because of the specific physiological features of the goat, this approach needs further validation. Previous reports on protein and energy requirements of lactating goats have been derived mainly from feeding trials and only a limited number of studies have published results on nitrogen and energy balance trials. $\mathrm{N}$ requirements for maintenance and milk production in lactating goats have been obtained by $\mathrm{N}$ balance studies by Khouri (1974), Sengar (1980), Rajpoot et al. (1981), Brun-Bellut et al. (1984) and Ciszuk \& Lindberg (1985). These studies indicate that, in goats, the $\mathrm{N}$ requirements for maintenance might be in agreement with reported findings for dairy cattle and sheep and also that the efficiency of use of dietary $\mathbf{N}$ for milk-protein synthesis appears to be somewhat lower than values given for dairy cattle. To our knowledge, the work of Armstrong \& Blaxter (1965), in which energy requirements for maintenance were estimated from measurements of fasting heat production, is the only study which examines the energy requirements for maintenance or production in the lactating goat. Due to the scarcity of original studies directly concerned with the assessment of nutrient requirements of the goat, the present work aims to provide additional information on this subject and to define specifically the energy and protein requirements of the lactating Granadina goat. 
Table 1. Chemical composition ( $\mathrm{g} / \mathrm{kg}$ dry matter) and energy content ( $M J / k g$ dry matter) of the experimental feed ingredients

\begin{tabular}{|c|c|c|c|c|}
\hline \multirow[b]{2}{*}{ Lactation no... } & \multicolumn{2}{|c|}{$\begin{array}{c}\text { Pelleted lucerne } \\
\text { (Medicago sativa) hay }\end{array}$} & \multicolumn{2}{|c|}{ Barley } \\
\hline & 1 & 2 & 1 & 2 \\
\hline Organic matter & 895 & 863 & 980 & 976 \\
\hline Crude protein (nitrogen $\times 6.25$ ) & 162 & 212 & 107 & 109 \\
\hline Apparent digestible $\mathrm{N}$ & $15 \cdot 8$ & $21 \cdot 0$ & 11.5 & $12 \cdot 4$ \\
\hline Gross energy & 18.73 & 17.53 & $18 \cdot 31$ & 18.50 \\
\hline Digestible energy & 8.90 & $8 \cdot 38$ & $14 \cdot 64$ & $15 \cdot 33$ \\
\hline Metabolizable energy & $7 \cdot 34$ & 7.02 & $12 \cdot 33$ & 13.62 \\
\hline Dry matter $(\mathrm{g} / \mathrm{kg})$ & 883 & 906 & 891 & 894 \\
\hline
\end{tabular}

\section{MATERIALS AND METHODS}

\section{Animals, diets and feeding}

Twelve goats of the Granadina breed in mid- and late lactation were used in two consecutive years. All animals had previously completed one lactation. During the last 6 weeks of pregnancy and also over the course of lactation they were allowed a diet based on pelleted lucerne (Medicago sativa) hay and barley. These feed ingredients had been evaluated in a previous experiment with adult castrated male goats (Prieto et al. 1990). The composition and nutritive value of these ingredients appear in Table 1. The diets also included, on a daily basis, $6 \mathrm{~g}$ sodium chloride and $4 \mathrm{~g}$ mineral plus vitamin premix containing $(\mathrm{g} / \mathrm{kg})$ : zinc $11 \cdot 3$, magnesium $45 \cdot 0$, manganese $7 \cdot 9$, iron $5 \cdot 5$, copper $2 \cdot 2$, cobalt $0 \cdot 11$, iodine $0 \cdot 11$, selenium $0 \cdot 023$, retinol $600 \mathrm{mg}$, cholecalciferol $10 \mathrm{mg}$. Water was always available. Individual animal feed intake was re-adjusted every $7 \mathrm{~d}$ to provide sufficient energy for maintenance plus milk yield based on the body-weight and milk yield observed in the preceding week, except during the balance periods when intake remained fixed. Maintenance was taken as $0.548 \mathrm{MJ}$ metabolizable energy (ME)/kg body-weight (W) $)^{\mathbf{0 . 7 5}}$ per $\mathrm{d}$ and the requirement for milk production as $4.9 \mathrm{MJ} \mathrm{ME} / \mathrm{kg} 4 \%$ fat-corrected milk (Aguilera et al. 1984). The diets were also formulated theoretically to provide sufficient rumen-degradable $\mathrm{N}$ (RDN) and undegradable $\mathrm{N}$ (UDN) to meet the requirements for maintenance plus milk production, as stated by the Agricultural Research Council (1980). The diets provided, on average, 1.30 $\mathrm{g} \mathrm{RDN} / \mathrm{MJ} \mathrm{ME}$ and 0.32 $\mathrm{g}$ UDN/MJ ME.

The goats were in lactation for 6-10 weeks, were then dosed with Tetramisol (Sobrino, S.A.) against internal parasites and allocated at random to metabolism cages in a temperature-controlled room $\left(24^{\circ}\right)$ on a $12 \mathrm{~h}$ light-12 h dark cycle. A total of six balance experiments were carried out, two in the first lactation and four during the second lactation. Each balance experiment consisted of a $20 \mathrm{~d}$ preliminary period followed by a $12 \mathrm{~d}$ collection period. After the second balance of the second lactation, the goats were removed from the metabolic cages and fed, as previously described, for 4 months before completing the remaining two balances. The $12 \mathrm{~d}$ collection periods were initiated when, on average, the goats were at weeks 9 and 14 of lactation in the first lactation and weeks 13, 18, 35 and 40 of the second lactation. The animals were fed once daily at 09.00 hours. The pelleted lucerne hay: barley ratio in the rations, on a dry matter basis, ranged from $35: 65$ to $46: 54$. Dry matter intakes of feed ingredients over the course of lactations appear in Table 2. Refusals of lucerne hay and barley were collected and recorded separately. Samples of feed and refusals were taken daily and samples for each collection period were pooled for 
Table 2. Mean values of live weight $(\mathrm{kg})$, intake $(\mathrm{g} / \mathrm{d})$, milk yield $(\mathrm{g} / \mathrm{d})$ and milk composition $(\mathrm{g} / \mathrm{kg})$ of lactating goats in mid-and late stages of two consecutive lactations (Values presented are means with their standard errors for twelve observations)

\begin{tabular}{|c|c|c|c|c|c|c|}
\hline \multirow{2}{*}{$\begin{array}{l}\text { Lactation no.... } \\
\text { Period of lactation (weeks) } \\
\text { Live wt (kg) }\end{array}$} & \multicolumn{2}{|c|}{1} & \multicolumn{4}{|c|}{2} \\
\hline & 9 & 14 & 13 & 18 & 35 & $40^{*}$ \\
\hline Mean & $34 \cdot 5$ & $34 \cdot 1$ & 40.6 & $40 \cdot 1$ & 40.6 & 41.4 \\
\hline $\mathrm{SE}$ & $1 \cdot 14$ & 1.38 & 1.58 & $1 \cdot 44$ & 1.49 & 1.69 \\
\hline \multicolumn{7}{|l|}{ Dry matter intake } \\
\hline \multicolumn{7}{|c|}{ Lucerne (Medicago sativa) hay } \\
\hline Mean & 416 & 394 & 646 & 512 & 453 & 453 \\
\hline $\begin{array}{c}\mathrm{SE} \\
\text { Barley }\end{array}$ & $29 \cdot 4$ & $41 \cdot 4$ & 37.5 & $26 \cdot 3$ & 0.1 & 0 \\
\hline \multicolumn{7}{|l|}{ Barley } \\
\hline Mean & 749 & 734 & 970 & 908 & 536 & 536 \\
\hline SE & $32 \cdot 3$ & $44 \cdot 5$ & 37.6 & 34.9 & 0.2 & 0 \\
\hline \multicolumn{7}{|l|}{ Milk yield } \\
\hline Mean & 1240 & 1094 & 1506 & 1344 & 483 & 381 \\
\hline $\mathrm{SE}$ & 76.6 & $66 \cdot 2$ & $112 \cdot 6$ & $109 \cdot 6$ & 58.9 & 52.0 \\
\hline \multicolumn{7}{|l|}{ Total solids } \\
\hline Mean & 146.5 & $149 \cdot 2$ & $151 \cdot 2$ & $151 \cdot 7$ & $203 \cdot 0$ & $193 \cdot 2$ \\
\hline SE & 2.74 & 2.53 & $2 \cdot 32$ & 2.93 & 8.88 & 4.69 \\
\hline \multicolumn{7}{|l|}{ Total nitrogen } \\
\hline Mean & 5.09 & $5 \cdot 46$ & 5.59 & $5 \cdot 43$ & $7 \cdot 72$ & $7 \cdot 44$ \\
\hline $\mathrm{SE}$ & 0.078 & 0.137 & 0.125 & 0.128 & 0.650 & 0.421 \\
\hline \multicolumn{7}{|l|}{ Fat } \\
\hline Mean & $59 \cdot 4$ & 58.8 & $57 \cdot 1$ & 59.7 & ND & ND \\
\hline $\mathrm{SE}$ & 1.850 & $3 \cdot 180$ & 1.425 & $2 \cdot 876$ & ND & ND \\
\hline \multicolumn{7}{|l|}{ Gross energy $(\mathrm{MJ} / \mathrm{kg})$} \\
\hline Mean & 3.63 & 3.60 & 3.49 & 3.65 & $5 \cdot 36$ & $5 \cdot 13$ \\
\hline $\mathbf{S E}$ & 0.106 & 0.089 & 0.081 & 0.091 & 0.292 & $0 \cdot 150$ \\
\hline
\end{tabular}

ND, not determined.

* Means of ten observations.

analysis. Faeces and urine were collected daily and representative samples were taken and stored at $-25^{\circ}$ until required for analysis. No preservative for urine was used. The animals were weighed at the beginning and end of each balance period.

\section{Respiration measurements}

Measurements of heat production (HP) were staggered as only two chambers were available. Throughout each balance experiment, on days $2,4,6,8,10$ or 12 of each $12 \mathrm{~d}$ collecting period, after a $24 \mathrm{~h}$ adaptation period, oxygen consumption and carbon dioxide and methane productions of each goat were measured for $24 \mathrm{~h}$ in open-circuit respiration chambers described elsewhere (Aguilera \& Prieto, 1986). HP was calculated from the respiratory exchange using the factors of Brouwer (1965). All animals had been previously trained to confinement and to the routine procedures of the chamber operations by feeding them in the chambers for at least three separate $24 \mathrm{~h}$ periods before respiration measurements. As difficulties had been experienced in collecting urine in the confined space of the respiration chambers, no collection of urine was made during the HP measurements.

\section{Milk recording and analysis}

The goats were hand-milked once daily at 08.00 hours and milk yield was recorded throughout the lactation. Collection of milk was made over two consecutive $5 \mathrm{~d}$ periods 
over the course of each balance experiment. Daily milk samples were preserved with potassium dichromate and kept at $4^{\circ}$. Pooled samples (from each milking) were analysed for total solids, fat, $\mathrm{N}$ and gross energy contents.

\section{Analytical methods}

$\mathrm{N}$ in feeds, wet faeces, urine and milk was measured by a Kjeldahl procedure using mineralization (Block Digestor Selecta S-509) distillation units (Büchi Laboratoriums Technik AG. Flawil, Switzerland; working capacity from 100 to $500 \mathrm{ml}$ ) and titration units from Metron AG, Herisau, Switzerland (Dosimat 655, Digital pH-Meter 632 and Impulsomat 614). Crude protein was calculated from the $\mathrm{N}$ content using the factor 6.25 ; the factor 6.38 was used for milk samples. Feeds were analysed for dry matter by oven drying at $103^{\circ}$ for $24 \mathrm{~h}$ and for organic matter by ashing at $550^{\circ}$. Total solids in milk were determined by freeze-drying $5 \mathrm{ml}$ of a well-mixed sample. Gross energy in feeds and in freeze-dried faeces, urine and milk was determined in an automated adiabatic calorimeter (Gallenkamp \& Co. Ltd, London). Samples of faeces, urine and milk were freeze-dried on a polyethylene sheet of known energy value and their gross energy values were obtained by difference. Other analyses were carried out by standard procedures (Association of Official Analytical Chemists, 1975).

\section{RESULTS}

\section{Milk yield and composition}

Two goats were withdrawn from the experiments in the fourth balance period of the second lactation due to their extremely low milk yield $(<0.050 \mathrm{~kg} / \mathrm{d})$. The mean daily milk production of goats in mid- and late lactation on two consecutive years is shown in Table 2. Milk yield ranged widely from 0.649 to $1.742 \mathrm{~kg} / \mathrm{d}$ in the first lactation and from 0.222 to $1.989 \mathrm{~kg} / \mathrm{d}$ in the second lactation. Within lactation, milk yield declined progressively between consecutive periods, this effect being particularly noticeable in the second lactation. Milk composition remained rather constant during the midstage of lactation (weeks 9-18 of lactation), the average content (/kg milk) for total solids, total $\mathrm{N}$, fat and gross energy being $149.7 \mathrm{~g}, 5.39 \mathrm{~g}, 58.8 \mathrm{~g}$ and $3.59 \mathrm{MJ}$ respectively. These variables increased during the late state of lactation (weeks 35 and 40 of the second lactation) and this change in composition moved in the opposite direction to the changes in milk yield.

\section{$N$ balance}

Table 3 shows the daily $\mathrm{N}$ balance of lactating goats over the course of the balance experiments. $\mathrm{N}$ intake (NI) ranged from 1.17 to 2.24 and from 1.24 to $2.75 \mathrm{~g} / \mathrm{kg} \mathrm{W}^{0.75}$ per $\mathrm{d}$ and values for $\mathrm{N}$ balance (milk $\mathrm{N}$ plus retained $\mathrm{N}, \mathrm{NB}$ ) from 0.29 to 1.02 and from 0.29 to $1.26 \mathrm{~g} / \mathrm{kg} \mathrm{W}^{0.75}$ per $\mathrm{d}$ in the first and second lactation experiments respectively.

When NB was regressed $v$. NI, a linear regression was obtained in each experiment. As these separate regressions did not differ significantly one from the other, a composite regression (Fig. 1(a)) was established on pooled data:

$$
\mathrm{NB}=0.510(\mathrm{SE} 0.038) \mathrm{NI}-0.244(\mathrm{SE} 0 \cdot 016), \quad r 0 \cdot 855, \quad \text { RSD } 0 \cdot 132,
$$

where NB and NI are expressed as $\mathrm{g} / \mathrm{kg} \mathrm{W}^{0.75}$ per $\mathrm{d}$ and RSD is the residual standard deviation. The overall efficiency of use of dietary $\mathrm{N}$ for $\mathrm{NB}$ was $51.0 \%$. At $\mathrm{N}$ equilibrium a daily intake of $478 \mathrm{mg} \mathrm{N} / \mathrm{kg} \mathrm{W}^{0.75}$ per $\mathrm{d}$ is required. From equation 1 a value for total endogenous $N$ (endogenous urinary $N$ plus metabolic faecal $\mathrm{N}$, TEN) of $244 \mathrm{mg} / \mathrm{kg} \mathrm{W}^{0.75}$ per $\mathrm{d}$ is obtained.

Endogenous urinary $\mathrm{N}(\mathrm{EUN})$ was estimated from a plot of urinary N (UN) against NI. 
Table 3. The daily nitrogen balance $\left(\mathrm{g} / \mathrm{kg}\right.$ body-weight $\left.{ }^{0.75}\right)$ of goats over the course of two consecutive lactations, each period consisting of $12 \mathrm{~d}$

(Values presented are means with their standard errors for twelve observations)

\begin{tabular}{|c|c|c|c|c|c|c|}
\hline \multirow{2}{*}{$\begin{array}{l}\text { Lactation no.... } \\
\text { Period of lactation (weeks) }\end{array}$} & \multicolumn{2}{|c|}{1} & \multicolumn{4}{|c|}{2} \\
\hline & 9 & 14 & 13 & 18 & 35 & $40^{*}$ \\
\hline \multicolumn{7}{|l|}{$\mathrm{N}$ intake } \\
\hline Mean & 1.72 & 1.56 & $2 \cdot 37$ & 2.04 & 1.56 & 1.53 \\
\hline SE & 0.073 & 0.095 & 0.111 & 0.107 & $0 \cdot 041$ & $0 \cdot 044$ \\
\hline \multicolumn{7}{|l|}{ Faecal N } \\
\hline Mean & 0.59 & 0.56 & 0.81 & 0.68 & 0.50 & 0.53 \\
\hline $\mathrm{SE}$ & 0.028 & $0 \cdot 036$ & $0 \cdot 039$ & 0.037 & 0.031 & 0.015 \\
\hline \multicolumn{7}{|l|}{ Apparent digestible $\mathrm{N}$} \\
\hline Mean & $1 \cdot 13$ & $1 \cdot 00$ & $1 \cdot 56$ & $1 \cdot 36$ & 1.06 & $1-00$ \\
\hline SE & 0.046 & 0.059 & 0.072 & 0.072 & 0.032 & 0.028 \\
\hline \multicolumn{7}{|l|}{ Urine $\mathrm{N}$} \\
\hline Mean & $0 \cdot 36$ & $0 \cdot 40$ & 0.55 & 0.68 & 0.55 & 0.52 \\
\hline $\mathrm{SE}$ & 0.018 & 0.035 & 0.035 & 0.035 & 0.037 & 0.029 \\
\hline \multicolumn{7}{|c|}{$\mathrm{N}$ balance (milk $\mathrm{N}+$ body $\mathrm{N}$ retention) } \\
\hline Mean & $0 \cdot 77$ & $0 \cdot 60$ & 1.01 & 0.68 & 0.51 & 0.48 \\
\hline $\mathrm{SE}$ & $0 \cdot 041$ & 0.049 & 0.068 & 0.066 & 0.041 & 0.035 \\
\hline \multicolumn{7}{|l|}{ Milk N output } \\
\hline Mean & 0.45 & 0.43 & 0.53 & $0 \cdot 46$ & $0 \cdot 17$ & $0 \cdot 16$ \\
\hline SE & 0.033 & $0 \cdot 036$ & 0.037 & 0.036 & 0.023 & $0-017$ \\
\hline \multicolumn{7}{|l|}{ Apparent body $\mathrm{N}$ retention } \\
\hline Mean & $0 \cdot 32$ & $0 \cdot 17$ & 0.48 & $0 \cdot 22$ & $0 \cdot 34$ & $0 \cdot 32$ \\
\hline $\mathrm{SE}$ & 0.030 & $0 \cdot 044$ & $0 \cdot 042$ & 0.037 & 0.035 & 0.034 \\
\hline
\end{tabular}

* Means of ten observations.

The composite regression was:

$$
\mathrm{UN}=0.154(\mathrm{SE} 0.027) \mathrm{NI}+0.218(\text { SE 0.025), } \quad r \text { 0.678, } \quad \text { RSD 0.077, }
$$

where UN and NI are expressed as $\mathrm{g} / \mathrm{kg} \mathrm{W}^{0.75}$ per $\mathrm{d}$.

From equation 2 a value of $218 \mathrm{mg} / \mathrm{kg} \mathrm{W}^{0.75}$ per $\mathrm{d}$ for EUN is obtained.

Two significant separate relationships between milk $\mathrm{N}$ output (MN) and dietary $\mathrm{N}$ intake (NI) for the two lactations were found (Fig. 1(b)):

$$
\begin{array}{ccc}
\mathrm{MN}=0.297(\mathrm{SE} 0.041) \mathrm{NI}-0.068(\mathrm{SE} 0.103), & r 0.737, & \text { RSD 0.080; } \\
\mathrm{MN}=0.388(\mathrm{SE} 0.028) \mathrm{NI}-0.397(\mathrm{SE} 0.055), & r 0.890, & \text { RSD } 0.086 \\
& n 46 \text { (2nd lactation), }
\end{array}
$$

where $\mathrm{MN}$ and $\mathrm{NI}$ are expressed as $\mathrm{g} / \mathrm{kg} \mathrm{W}^{0.75}$ per $\mathrm{d}$.

\section{Energy metabolism}

The daily energy balance of goats over the course of two consecutive lactations appears in Table 4. Apparent body energy retention was calculated by subtracting the energy output in faeces, urine, methane, HP and milk from the gross energy intake.

As had been planned, a considerable variation in milk production within animals was observed, as well as large changes in apparent body energy retention, which ranged from -324 to $353 \mathrm{~kJ} / \mathrm{kg} \mathrm{W}^{\mathbf{0} 75}$ per $\mathrm{d}$. The overall apparent body energy balance was negative in the first lactation and positive in the second lactation. 

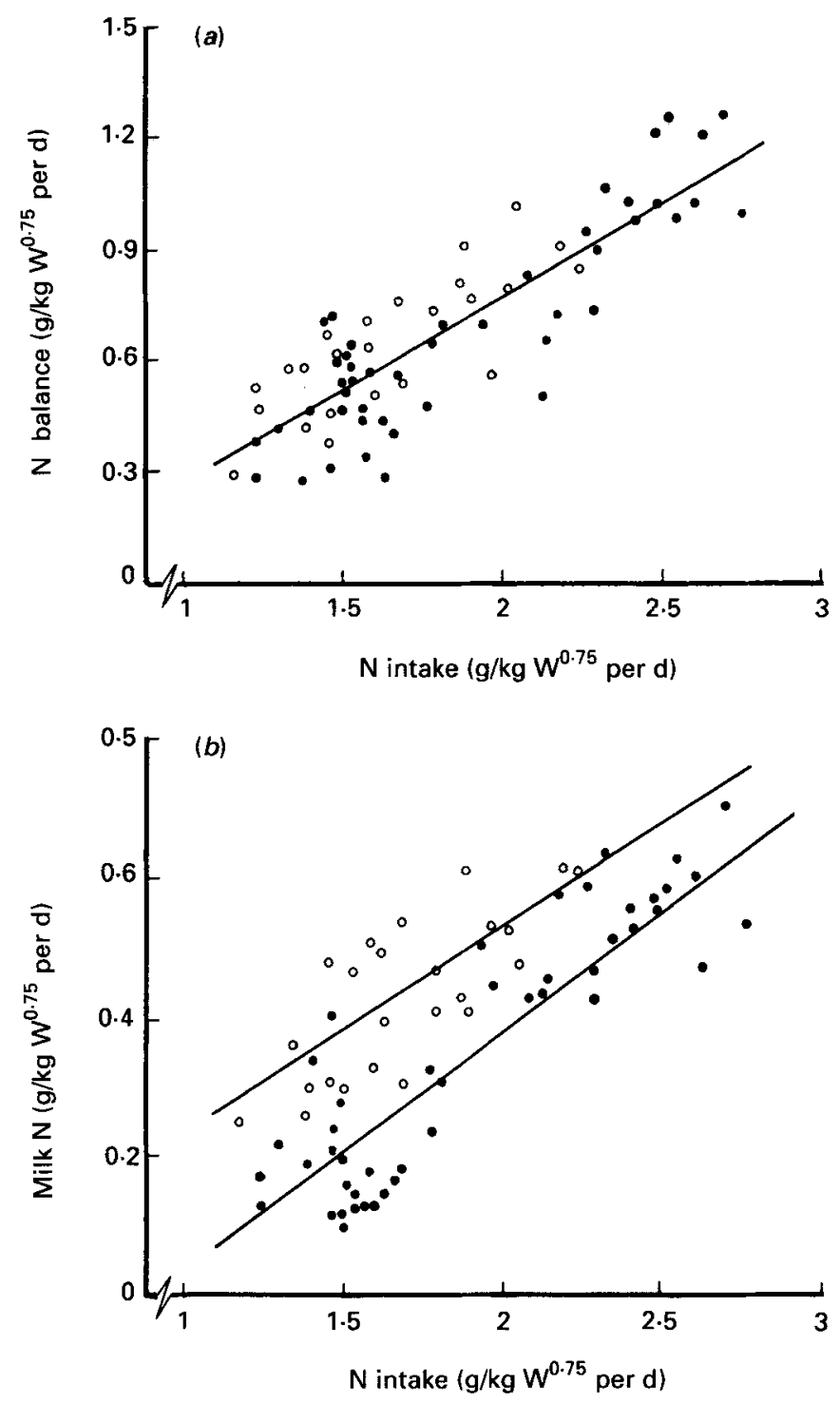

Fig. 1. Nitrogen balance (milk $\mathrm{N}+$ retained $\mathrm{N}$ ) $(a)$ or milk $\mathrm{N}(b) v . \mathrm{N}$ intake, all expressed as $\mathrm{g} / \mathrm{kg}$ body-weight $(\mathrm{W})^{\mathbf{0} \cdot 75}$ per $\mathrm{d}$, in lactating goats during two consecutive lactations (no. $1(\mathrm{O})$, no. $2(\mathrm{O})$ ).

Milk energy yield (YE) plus apparent body energy retention or loss (RE) was regressed v. ME intake. The best fitting line gave a linear relationship. As there were no statistical differences between separate regressions established within lactation experiments, an overall regression on pooled values was obtained:

$$
\mathrm{YE}+\mathrm{RE}=0.669(\mathrm{SE} 0.037) \mathrm{ME}-268(\mathrm{SE} 7 \cdot 1), \quad r 0.909, \quad \text { RSD 59.5, }
$$

where YE, RE and ME are all expressed as $\mathrm{kJ} / \mathrm{kg} \mathrm{W}^{0.75}$ per $\mathrm{d}$. This equation provides an estimate of the efficiency of use of ME for productive purposes $(66.9 \%)$ and also predicts the maintenance energy requirement $\left(\mathrm{ME}_{\mathrm{m}}\right)$, when $\mathrm{YE}+\mathrm{RE}=0$, as $401 \mathrm{~kJ} / \mathrm{kg} \mathrm{W}^{0.75}$ per d. 
Table 4. The daily energy balance $\left(k J / k g\right.$ body-weight $\left.{ }^{0.75}\right)$ of goats over the course of two consecutive lactations, each period consisting of $12 \mathrm{~d}$

(Values presented are means with their standard errors for twelve observations)

\begin{tabular}{|c|c|c|c|c|c|c|}
\hline \multirow{2}{*}{$\begin{array}{l}\text { Lactation no.... } \\
\text { Period of lactation (weeks) }\end{array}$} & \multicolumn{2}{|c|}{1} & \multicolumn{4}{|c|}{2} \\
\hline & 9 & 14 & 13 & 18 & 35 & $40^{*}$ \\
\hline \multicolumn{7}{|l|}{ Gross energy intake } \\
\hline Mean & 1564 & 1422 & 1792 & 1596 & 1119 & 1103 \\
\hline SE & $58 \cdot 7$ & $77 \cdot 0$ & $79 \cdot 6$ & $81 \cdot 7$ & $28 \cdot 6$ & $31 \cdot 3$ \\
\hline \multicolumn{7}{|l|}{ Energy in faeces } \\
\hline Mean & 500 & 450 & 546 & 463 & 366 & 361 \\
\hline SE & $25 \cdot 5$ & $33 \cdot 6$ & $26 \cdot 4$ & $25 \cdot 6$ & $9 \cdot 3$ & $10 \cdot 2$ \\
\hline \multicolumn{7}{|l|}{ Energy in urine } \\
\hline Mean & 80 & 87 & 79 & 50 & 38 & 17 \\
\hline SE & $7 \cdot 8$ & $10 \cdot 1$ & $8 \cdot 8$ & $9 \cdot 9$ & $3 \cdot 0$ & $3 \cdot 4$ \\
\hline \multicolumn{7}{|l|}{ Energy in methane } \\
\hline Mean & 89 & 83 & 117 & 111 & 97 & 97 \\
\hline $\mathrm{SE}$ & $8 \cdot 0$ & 6.9 & 6.7 & $8 \cdot 0$ & $2 \cdot 4$ & $2 \cdot 4$ \\
\hline \multicolumn{7}{|l|}{ Metabolizable energy intake } \\
\hline Mean & 895 & 802 & 1050 & 972 & 618 & 628 \\
\hline SE & $26 \cdot 8$ & $36 \cdot 1$ & $44 \cdot 7$ & $47 \cdot 1$ & $16 \cdot 0$ & $17 \cdot 0$ \\
\hline \multicolumn{7}{|l|}{ Heat production } \\
\hline Mean & 594 & 562 & 611 & 544 & 465 & 464 \\
\hline SE & $20 \cdot 2$ & $21 \cdot 5$ & $15 \cdot 7$ & $30 \cdot 9$ & $11 \cdot 3$ & $8 \cdot 1$ \\
\hline \multicolumn{7}{|c|}{ Total energy retained $(Y E+R E)$} \\
\hline Mean & 301 & 240 & 439 & 428 & 153 & 164 \\
\hline SE & $16 \cdot 0$ & $33 \cdot 6$ & $38 \cdot 7$ & $33 \cdot 3$ & $15 \cdot 1$ & $13 \cdot 7$ \\
\hline \multicolumn{7}{|l|}{ Milk energy (YE) } \\
\hline Mean & 326 & 286 & 329 & 308 & 130 & 118 \\
\hline $\mathrm{SE}$ & $30 \cdot 2$ & $23 \cdot 5$ & $23 \cdot 1$ & $23 \cdot 3$ & $21 \cdot 4$ & 15.2 \\
\hline \multicolumn{7}{|c|}{$\begin{array}{l}\text { Body energy retention }(+) \text { or loss } \\
(-)(\mathrm{RE})\end{array}$} \\
\hline Mean & -25 & -46 & 110 & 120 & 23 & 46 \\
\hline $\mathrm{SE}$ & $25 \cdot 8$ & $39 \cdot 3$ & $20 \cdot 4$ & $25 \cdot 0$ & $26 \cdot 7$ & $19 \cdot 8$ \\
\hline
\end{tabular}

* Means of ten observations.

The efficiency of use of ME for lactation when there is no change in body-energy stores $\left(k_{1}\right)$ was calculated according to the Agricultural Research Council (1980). Energy lost from the body, indicating a mobilization of body fat reserves in support of milk secretion, was assumed to be used for milk synthesis with an efficiency of 0.84 and the concomitant energy storage during lactation was taken to be 0.95 times as efficient as milk secretion. Consequently, the corrected milk energy yield $\left(\mathrm{YE}_{\mathrm{c}}\right)$ was estimated as milk energy (milk E) $+(0.84 \times$ negative energy retention $)+(1.05 \times$ positive energy retention $)$.

When regressing $\mathrm{YE}_{\mathrm{c}} v . \mathrm{ME}$ intake (Fig. 2), the following equation was obtained with values from both positive and negative energy retentions:

$$
\mathrm{YE}_{\mathrm{c}}=0.667 \text { (SE 0.036) ME - 258 (SE 6.8), } \quad r \text { 0.914, RSD 57.3, }
$$

where $\mathrm{YE}_{\mathrm{c}}$ and $\mathrm{ME}$ are expressed as $\mathrm{kJ} / \mathrm{kg} \mathrm{W}^{0.75}$ per $\mathrm{d}$. This equation, giving the best fitting line, indicates an efficiency of use of ME for lactation of $66.7 \%$.

In case of concomitant energy deposition the equation found was:

$$
\mathrm{YE}_{\mathrm{c}}=0.657 \text { (SE 0.038) ME }-237 \text { (SE 7.3), } \quad r 0.935, \quad \text { RSD 49.4; } n \text { 46, }
$$

where $\mathrm{YE}_{\mathrm{c}}$ and $\mathrm{ME}$ are both expressed as $\mathrm{kJ} / \mathrm{kg} \mathrm{W}^{0.75}$ per $\mathrm{d}$. In this case, when milk energy yield (YE) and apparent body energy retention (RE) were both expressed as a percentage 


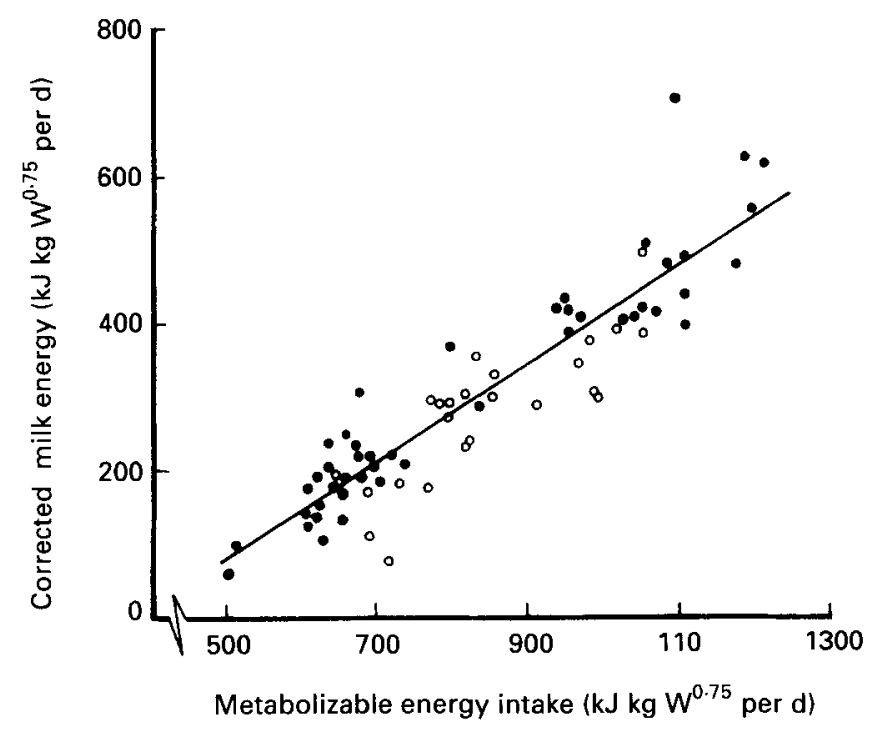

Fig. 2. Corrected milk energy yield $v$. metabolizable energy intake, all expressed as $\mathrm{kJ} / \mathrm{kg}$ body-weight $(\mathrm{W})^{0 \cdot 75}$ per $\mathrm{d}$, in lactating goats during two consecutive lactations (no. $1(\mathrm{O})$, no. $2(0)$ ).

of $\mathrm{ME}$ intake above maintenance $\left(\mathrm{ME}_{\mathrm{p}}\right)$ using for $\mathrm{ME}_{\mathrm{m}}$ the value of $401 \mathrm{~kJ} / \mathrm{kg} \mathrm{W} \mathrm{W}^{0.75}$ per $\mathrm{d}$ (equation 5), and RE was regressed $v$. YE, according to the procedure described by Armstrong \& Blaxter (1965) in experiments with lactating goats, the following equation was obtained:

$$
\begin{aligned}
\mathrm{RE} / 100 \mathrm{~kJ} \mathrm{ME} & =-0.907(\mathrm{SE} 0.088) \mathrm{YE} / 100 \mathrm{~kJ} \mathrm{ME} \\
& +67.6(\mathrm{SE} 1.62), \\
& r 0.671, \quad \text { RSD } 12.47, \quad n 46 .
\end{aligned}
$$

Equation 8 suggests that a fall in milk energy yield of $1 \mathrm{~kJ}$ was associated with an increase in body energy store of 0.907 . In addition, the intercept of this equation indicates that a change in milk production to zero milk energy secretion/100 kJ ME given above maintenance would result in an increase of body energy retention of $67.6 \mathrm{~kJ}$. Alternatively, at zero body energy retention $/ 100 \mathrm{~kJ} \mathrm{ME}$, the output of milk energy would be $74.5 \mathrm{~kJ} / 100 \mathrm{~kJ} \mathrm{ME}$.

\section{DISCUSSION}

\section{$N$ balance}

In the present work values of TEN and EUN losses of 244 and $218 \mathrm{mg} / \mathrm{kg} \mathrm{W}^{0 \cdot 75}$ per $\mathrm{d}$ were obtained. These results suggest that in lactating goats EUN is by far the main endogenous $\mathrm{N}$ loss, in agreement with our results for non-lactating goats (Prieto et al. 1990).

There are wide variations between the few literature values of daily EUN losses for nonlactating goats, ranging from $40 \mathrm{mg} \mathrm{N} / \mathrm{kg} \mathrm{W}^{0 \cdot 75}$ per d in dwarf goats (Akinsoyinu et al. 1976) to $240 \mathrm{mg} \mathrm{N} / \mathrm{kg} \mathrm{W}^{0.75}$ per d in castrated male goats (Itoh et al. 1978), although most of them are in the vicinity of $125 \mathrm{mg} \mathrm{N} / \mathrm{kg} \mathrm{W}^{0.75}$ per d (Majumdar, 1960; Rajpoot et al. 1980; Reynolds, 1981 ; Devendra, 1982; Guerrero, 1982). The value of $218 \mathrm{mg} \mathrm{N} / \mathrm{kg} \mathrm{W}^{0.75}$ per d derived from equation 2 is at the top of the range of the values mentioned previously, but compares well with the estimate of $229 \mathrm{mg} \mathrm{N} / \mathrm{kg} \mathrm{W}^{0.75}$ per d found in lactating goats by Ciszuk \& Lindberg (1985). It is higher than that of $119 \mathrm{mg} / \mathrm{kg} \mathrm{W}^{0.75}$ per d, which was obtained for non-lactating goats fed on similar diets in our laboratory (Prieto et al. 1990). 
The results suggest that the lactating goat has an increased endogenous loss of urinary $\mathrm{N}$ in comparison with the non-productive goat.

The maintenance requirement for $\mathrm{N}$ in lactating goats estimated in the present paper from equation 1 (478 $\mathrm{mg}$ total $\mathrm{N} / \mathrm{kg} \mathrm{W}^{0.75}$ per $\mathrm{d}$ ) is in agreement with those of 477,457 and $503 \mathrm{mg}$ total $\mathrm{N} / \mathrm{kg} \mathrm{W}^{0.75}$ per $\mathrm{d}$ which can be calculated from the experiments in lactating goats of Khouri (1974), Brun-Bellut et al. (1984) and Ciszuk \& Lindberg (1985) respectively, assuming an average apparent digestibility for total dietary $\mathrm{N}$ of $70 \%$. On the other hand, our requirement is lower than the values for lactating goats reported by Sengar (1980), which are in the range of 716-876 $\mathrm{mg}$ total $\mathrm{N} / \mathrm{kg} \mathrm{W}^{0.75}$ per $\mathrm{d}$, and by Rajpoot et al. (1981) (1131 mg total N/kg W ${ }^{0.75}$ per d). Also, our value of 478 is higher than that of $409 \mathrm{mg}$ total $\mathrm{N} / \mathrm{kg} \mathrm{W}^{0.75}$ per $\mathrm{d}$, which was obtained for non-lactating goats given similar diets (Prieto et al. 1990). This latter observation is consistent with the higher endogenous $\mathrm{N}$ losses found in the lactating animal in comparison with those observed in the castrated male goat.

Values for dairy cows from Wageningen (Boekholt, 1972) showed the relationship between the milk $\mathrm{N}$ output plus the $\mathrm{N}$ retained in tissues (NB) and the intake of apparently digested $\mathrm{N}(\mathrm{ND})$ of $\mathrm{NB}=0.74 \mathrm{ND}-22.26$. The slope of this regression indicates an efficiency of use of ND for productive purposes which agrees well with that of 0.510 (equation 1) when an average apparent digestibility for total $\mathrm{N}$ of 0.70 is assumed.

\section{Energy metabolism}

The $\mathrm{ME}_{\mathrm{m}}$ in the present paper was estimated to be $401 \mathrm{~kJ} / \mathrm{kg} \mathrm{W^{0.75 }}$ per d (equation 5), a value which is slightly lower than that observed in experiments (Prieto et al. 1990) with adult castrated male goats $\left(443 \mathrm{~kJ} / \mathrm{kg} \mathrm{W}^{0 \cdot 75}\right.$ per d). Consequently, no differences in metabolic rate at maintenance have been found between lactating and non-lactating goats in contrast to available results from dairy cows, suggesting that the lactating animal has a somewhat higher $\mathrm{ME}_{\mathrm{m}}$ than the dry animal (Moe et al. 1970; Patle \& Mudgal, 1977; Van Es \& Van der Honing, 1979). No previous reports have been found based on calorimetric trials on energy requirements for maintenance or production in the lactating goat, with the exception of that of Armstrong \& Blaxter (1965). Their experiment measured fasting HP $\left(236 \mathrm{~kJ} / \mathrm{kg} \mathrm{W}^{0.73}\right.$ per d) and from this a maintenance requirement of $319 \mathrm{~kJ} / \mathrm{kg} \mathrm{W}^{0.73}$ per $\mathrm{d}$ can be calculated assuming a constant efficiency for the use of ME for maintenance of $73.9 \%$. Our estimate of $\mathrm{ME}_{\mathrm{m}}$ is lower than those published for milking cows $(510 \mathrm{~kJ} / \mathrm{kg}$ $\mathrm{W}^{0.75}$ per d, Moe et al. (1970); $523 \mathrm{~kJ} / \mathrm{kg} \mathrm{W}^{0.75}$ per d, Van der Honing \& Van Es (1974)) and higher than those reported for sheep of similar weight $\left(318 \mathrm{~kJ} / \mathrm{kg} \mathrm{W}^{0.75}\right.$ per d, Agricultural Research Council (1980)).

The efficiency of use of ME for lactation of $66.7 \%$ obtained from equation 6 is slightly higher than the top value of the range of theoretical values based on biochemical considerations $(0 \cdot 60-0.65)$ and is about four percentage units higher than the value obtained from the equation $k_{1}=0.35 q_{\mathrm{m}}+0.420$ (Agricultural Research Council, 1980) when the average metabolizability of the ration $\left(q_{\mathrm{m}}\right)$ of 0.58 found in the present experiments is taken. This increased efficiency may be attributed to the use of pelleted lucerne hay as a component of the experimental diets since pelleting has been proved to cause an increase in the efficiency of energy use for lactation (Van der Honing \& Van Es, 1974). However, Armstrong \& Blaxter (1965) reported a similar value of $69 \cdot 1$ for the efficiency of use of ME for milk synthesis. Therefore there appears to be very little difference in the efficiency of use of ME for lactation between goats, cattle or sheep. Also, from equation 6 it can be calculated that 5.38 MJ ME are required for the production of $1 \mathrm{~kg}$ goat milk with an average energy content of $3.59 \mathrm{MJ} / \mathrm{kg}$ or $4.20 \mathrm{MJ} \mathrm{ME} / \mathrm{kg} 4 \%$ fatcorrected milk. The National Research Council (1981) gives a value of $5.21 \mathrm{MJ} \mathrm{ME} / \mathrm{kg} 4 \%$ 
fat-corrected milk based on a mean of four feeding trials. This value is similar to that of $5 \cdot 1 \mathrm{MJ} \mathrm{ME} / \mathrm{kg} 4 \%$ fat-corrected milk (Agricultural Research Council, 1980) for dairy cattle. French recommended allowances for dairy cattle are 4.35 MJ ME/kg 3.5\% standard milk (Morand-Fehr et al. 1987).

Equation 8 predicts that the efficiency of concomitant energy storage during lactation is 0.91 times that for milk secretion. This value compares well with the value of 0.96 obtained by Armstrong \& Blaxter (1965) in goats. Although the difficulty of estimating the efficiency with which $\mathrm{ME}$ is used to promote energy retention in the body during lactation has been widely recognized, most authors agree that this efficiency is higher than that in the nonlactating animal. Literature values range from 0.78 to 1.13 (Mollgaard, 1929; Armstrong \& Blaxter, 1965; Moe et al. 1970; Van Es et al. 1970; Patle \& Mudgal, 1977) and the Agricultural Research Council (1980) has assumed an efficiency of 0.95 times that for milk energy yield.

At present insufficient information is available to prove conclusively whether or not protein and energy requirements derived from other ruminants can be applied to the goat. On the basis of the results reported in the present paper it is proposed that the use of feeding systems based on values in cattle and sheep are likely to be suitable for lactating goats.

The authors wish to thank Mrs E. Colmenero and Miss F. Gil for skilful technical assistance and $\mathrm{Mr}$ A. Velázquez for the care of animals. This work was supported by the Junta de Andalucía and the Spanish Research Council (Project no. 316).

\section{REFERENCES}

Agricultural Research Council (1980). The Nutrient Requirements of Ruminant Livestock. Slough: Commonwealth Agricultural Bureaux.

Aguilera, J. F., Guerrero, J. E., Molina, E. \& Boza, J. (1984). Eficiencia de utilización energética para la lactación en ganado caprino. $9^{\text {as }}$ Jornadas Cientificas de la Sociedad Española de Ovinotecnia y Caprinotecnia, pp. 305-310. Granada y Málaga: Excmas. Diputaciones Provinciales.

Aguilera, J. F. \& Prieto, C. (1986). Description and function of an open-circuit respiration plant for pigs and small ruminants and the techniques used to measure energy metabolism. Archives of Animal Nutrition Berlin 36, $1009-1018$.

Akinsoyinu, A. O., Mba, A. U. \& Olubayo, F. O. (1976). Crude protein requirement of West African Dwarf goats for maintenance and gain. Journal of the Association for the Advancement of Agricultural Sciences in Africa 3, 75-80.

Armstrong, D. G. \& Blaxter, K. L. (1965). Effects of acetic and propionic acids on energy retention and milk secretion in goats. In Proceedings of the 3rd European Association for Animal Production Symposium on Energy Metabolism, Publication no. 11, pp. 59-70 [K. L. Blaxter, editor]. London: Academic Press.

Association of Official Analytical Chemists (1975). Official Methods of Analysis, 12th ed. Washington DC: AOAC.

Boekholt, H. A. (1972). Cited by Agricultural Research Council (1980).

Brouwer, E. (1965). Report of sub-committee on constants and factors. In Proceedings of 3rd European Association for Animal Production Symposium on Energy Metabolism, Publication no. 11, pp. $441-443$ [K. L. Blaxter, editor]. London: Academic Press.

Brun-Bellut, J., Blanchart, G. \& Vignon, B. (1984). Détermination des besoins azotés de la chèvre en lactation. Annales de Zootecnie 33, 171-186.

Ciszuk, P. \& Lindberg, J. E. (1985). Total nitrogen retention in lactating goats in relation to digested nitrogen and estimated absorption of amino acids. Acta Agriculturae Scandinavica 25, Suppl., 163-176.

Devendra, C. (1982). The protein requirements for maintenance of indigenous Kambing Katjang goats in Malaysia. Nutrition Abstracts and Reviews 52, 281.

Guerrero, J. E. (1982). Estudio de la alimentación del ganado caprino. Utilización de subproductos y ensayos de lactación en cabras de raza Granadina. PhD Thesis, University of Córdoba.

Itoh, M., Haryu, T., Tano, R. \& Iwasaki, K. (1978). Maintenance requirement of energy and protein for castrated Japanese native goats. Bulletin of National Institute of Animal Industry no. 33, pp. 41-50. Nishigoshi, Kumamoto: Kyushu National Agricultural Experimental Station.

Khouri, S. (1974). Contribution à l'étude de l'évaluation de l'éfficacité nutritive des protéines tannées chez le ruminant (cas particulier de la chèvre laitière). $\mathrm{PhD}$ Thesis, University of Languedoc. 
Majumdar, B. N. (1960). Studies on goat nutrition. I. Minimum protein requirements for maintenance, endogenous urinary nitrogen and metabolic faecal nitrogen excretion studies. Journal of Agricultural Science, Cambridge 54, 329-334.

Moe, P. W., Tyrrell, H. F. \& Flatt, W. P. (1970). Partial efficiency of energy use for maintenance, lactation, body gain and gestation in the dairy cow. In Proceedings of 5th European Association for Animal Production Symposium on Energy Metabolism of Farm Animals, Publication no. 13, pp. 65-68 [A. Schürch and C. Wenk, editors]. Zürich: Juris Druck \& Verlag.

Mollgaard, H. (1929). Futterungslehre des Milchviehs. Hannover: M. \& H. Schaper.

Morand-Fehr, P., Sauvant, D. \& Brun-Bellut, J. (1987). Recommendations alimentaires pour les caprins. Bulletin Technique C.R.Z.V. Theix, I.N.R.A. 70, 213-222.

National Research Council (1981). Nutrient Requirements of Domestic Animals, Publication no. 15. Washington, DC: National Academy Press.

Patle, B. R. \& Mudgal, V. D. (1977). Utilization of dietary energy for maintenance, milk production and lipogenesis by lactating crossbred cows during their midstage of lactation. British Journal of Nutrition 37, 23-33.

Prieto, C., Aguilera, J. F., Lara, L. \& Fonollá, J. (1990). Protein and energy requirements for maintenance of indigenous Granadina goats. British Journal of Nutrition 63, $155-163$.

Rajpoot, R. L., Sengar, O. P. S. \& Singh, S. N. (1980). Goats: protein requirement for maintenance. International Goat and Sheep Research 1, 182-189.

Rajpoot, R. L., Sengar, O. P. S. \& Singh, S. N. (1981). Energy and protein in goat nutrition. In Nutrition and Systems of Goat Feeding, vol. 1, pp. 101-124 [P. Morand-Fehr, A. Bourbouze and M. de Simiane, editors]. Tours: ITOVIC-INRA.

Reynolds, L. (1981). Nitrogen metabolism in indigenous Malawi goats. Journal of Agricultural Science, Cambridge 96, 347-351.

Sengar, O. P. S. (1980). Indian research on protein and energy requirements of goats. Journal of Dairy Science 63 , $1655-1670$.

Van der Honing, Y. \& Van Es, A. J. H. (1974). Utilization of energy from pelleted roughages in dairy cattle rations. In Proceedings of 6th European Association for Animal Production Symposium on Energy Metabolism of Farm Animals, Publication no. 14, pp. 209-212 [K. H. Menke, H. J. Lantzsch and J, R. Reichi, editors]. Hohenheim: Universität Dokumentationsstelle.

Van Es, A. J. H., Nijkamp, H. J. \& Vogt, J. E. (1970). Feed evaluation for dairy cows. In Proceedings of 5th European Association for Animal Production Symposium on Energy Metabolism of Farm Animals, Publication no. 13, pp. 61-64 [A. Schürch and C. Wenk, editors]. Zürich: Juris Druck \& Verlag.

Van Es, A. J. H. and Van der Honing, Y. (1979). Energy utilisation. In Feeding Strategy for the High Yielding Dairy Cow, pp. 68-69 [W. H. Broster and H. Swan, editors]. St Allans: Granada Publishing. 